\title{
Declining prevalence of hepatitis $C$ virus among university students in one of the main governorates in Egypt
}

This article was published in the following Dove Press journal:

Infection and Drug Resistance

\author{
Yousry Esam-Eldin Abo- \\ Amer \\ Sherief Abd-Elsalam² \\ Hazim Eldosoky ${ }^{3}$ \\ Amira K ELShenawy ${ }^{4}$ \\ Shereen Awny ${ }^{5}$ \\ Waleed Elagawy ${ }^{6}$ \\ Mohamed El Abgeegy ${ }^{6}$ \\ Heba Fadl Elsergany ${ }^{6}$ \\ Heba Elashry ${ }^{2}$ \\ Manal Saad $\mathrm{Negm}^{5}$
}

'Hepatology, Gastroenterology and Infectious Diseases Department, Mahala Hepatology Teaching Hospital, Gharbia, Egypt; ${ }^{2}$ Tropical Medicine Department, Tanta University, Tanta, Egypt; ${ }^{3}$ Clinical Pathology Department, Student Hospital, Menoufia University, Menoufia, Egypt; ${ }^{4}$ Public Health and Community Medicine Department, Tanta University, Tanta, Egypt; ${ }^{5}$ Internal Medicine Department, Tanta University, Tanta, Egypt; ${ }^{6}$ Tropical Medicine Department, National Hepatology and Tropical Medicine Research Institute in Cairo, Cairo, Egypt
Correspondence: Sherief Abd-Elsalam Tropical Medicine Department, Tanta University, El-Geish Street, Tanta, Egypt Tel +20 I09 5 I5 9522

Email Sherif_tropical@yahoo.com
Background and aims: Egypt is considered to have the highest rate of hepatitis $\mathrm{C}$ virus (HCV) prevalence worldwide. However, HCV prevalence is currently declining due to the improvement of health education programs, improved environmental sanitation, and the introduction of novel treatment regimens. The aim of this work was to determine the HCV seroprevalence among Menoufia University students.

Methods: The current study included 48,972 students from Menoufia University, Egypt. Blood sample was obtained from every patient for HCV seromarker testing. In anti-HCV-positive subjects, quantitative PCR for HCV RNA was done.

Results: Overall, HCV antibody prevalence rate was $1 \%$. This prevalence was higher in females $(304 / 27,421 ; 1.1 \%)$ than in males $(194 / 21,371 ; 0.9 \%)$. HCV-RNA PCR was positive in $355 / 48,972(0.7 \%)$; the percentage of HCV PCR positive among the anti-HCV-positive was $71.3 \%$ (355/498 patients), with a higher prevalence among females than in males but without statistical significance. In addition, rural areas showed more prevalent HCV seroprevalence than urban areas.

Conclusion: These prevalence rates for HCV infection are lower than that previously reported in the same age group denoting a new evidence for the reduction of prevalence and a hope for successful eradication of $\mathrm{HCV}$ in the forthcoming years.

Keywords: HCV, prevalence, Egypt, students, Menoufia University, hepatitis C virus, infection, treatment, direct acting antiviral, DAA, eradication

\section{Introduction}

Hepatitis $\mathrm{C}$ virus (HCV) affects $2 \%-3 \%$ of the world's population (130-170 million persons). ${ }^{1} \mathrm{HCV}$ prevalence is considerably low $(<2 \%)$ in Australia, most countries in Western Europe and USA. ${ }^{2}$ In Egypt, the situation is highly surprising. Egypt was considered as plagued with the highest rate of $\mathrm{HCV}$ prevalence worldwide. ${ }^{3}$ Parenteral antischistosomal mass treatment campaigns (20-50 years ago) have been suggested to be the underlying cause for the high HCV prevalence in Egypt. ${ }^{4-6}$ An Egyptian Demographic Health Survey (EDHS) was accomplished in 2008, which concluded that HCV antibodies and HCV RNA were prevalent in $14.7 \%$ and 9.8\%, respectively. ${ }^{7}$ A systematic review was published in 2013 concluded that there is no evidence of a statistically significant decline in the prevalence of HCV over time in both the general and high-risk populations. ${ }^{8}$

After start of direct acting antiviral (DAA) era in Egypt, the previously reported rates varied significantly in a more recent EDHS that was performed in 2015, which reported reduced prevalence of anti-HCV of $10 \%$ and HCV RNA of 7\%. ${ }^{9}$ In 2013 , 
a realistic estimate of $\mathrm{HCV}$ incidence declared it to be $<150,000 .{ }^{10}$ While $30 \%$ of patients clear the virus spontaneously, the main health burden occurs to the majority of patients who further develop chronic $\mathrm{HCV}$ with subsequent cirrhosis and its drastic sequelae. ${ }^{11-14}$ Moreover, consequent severe fibrosis, which usually occurs with prolonged and chronic HCV infection, is one of the important factors that negatively impact viral clearance and sustained virologic response rates. ${ }^{15}$

Recent studies indicated that that HCV prevalence in Egypt is declining due to factors such as improvement of health education programs and improved environmental sanitation. However, the true playmaker for such reduction of $\mathrm{HCV}$ prevalence is believed to be the successful introduction of novel DAA agents and nationwide program for HCV management. ${ }^{16-21}$

$\mathrm{HCV}$ is rarely transmitted by blood transfusion or organ transplantation because of careful testing of blood and blood products for the presence of the virus and the disabling procedures that destroy blood-borne viruses. The prevalence of $\mathrm{HCV}$ among household contacts for people with $\mathrm{HCV}$ infection is low. Care providers only need to advise patients to take "common sense" precautions such as not sharing items that may contain blood (eg, razors and toothbrushes) and covering wounds or open wounds properly. Health care workers exposed to blood are at risk of developing HCV and other blood-borne pathogens. However, the incidence of HCV infection is not greater in health care workers, including surgeons, than in the general population. ${ }^{22}$

The aim of this work was to determine the HCV seroprevalence among Menoufia University students to assess the dynamic changes in the prevalence as compared to previous reports.

\section{Patients and methods}

This screening program included 48,792 undergraduate students in Menoufia University. The study was enrolled in the corresponding Student Hospital to Menoufia University during the period April 2017 to October 2017. These students were 21,371 males and 27,421 females who offered to be tested for HCV seromarker.

All students signed a written informed consent prior to the inclusion to this study, and the Tanta University Faculty of Medicine research ethical committee approved the study. The study protocol conforms to the ethical guidelines of the 1975 Declaration of Helsinki.

Testing for HCV antibodies was done using a rapid anti$\mathrm{HCV}$ enzyme immunoassay test kit. The rapid test assisted in a fast detection of HCV antibodies and giving the results within
15 minutes. This test is based on immune-chromatography; the overall specificity of the test was found to be above $95 \%$. Positive tests were confirmed with PCR for HCV RNA, HCV RNA quantitative by TaqMan real-time PCR. The Cobas Ampliprep/ Cobas TaqMan (CAP/CTM) is fully automated real-time PCR.

\section{Procedure principle}

In this test, all samples were fresh and were used immediately. The applied HCV antigens were recombinant proteins that were identical to strong immune reactive regions with the overall specificity of $97 \%-99 \%$. The obtained blood samples were immediately added to a provided diluent. The $\mathrm{HCV}$ antigen in colloidal gold conjugate established in the sample pad reacted with the HCV antibody in the blood. This led to formation of a HCV/antibody complex conjugate. This conjugate was spread along the test strip reaching the colored test band. A negative sample was obtained when the test line was absent. At the end of the test, a colored control band appeared in the control region whatever the test result which indicated the test validity.

\section{HCV RNA quantitative by TaqMan real- time PCR}

All HCV antibody-positive subjects provided blood samples for HCV RNA testing. The CAP/CTM was fully automated real-time PCR.

\section{Statistical analysis}

Patient data were statistically analyzed using SPSS. For quantitative variables, data were expressed as mean and standard deviation and compared using unpaired Student's $t$-test. For qualitative variables, data were expressed as frequency and percentage. Chi-squared test or Fischer's exact test was used for comparing between groups. $P$-values $<0.05$ and $<0.01$ were considered statistically significant and highly significant, respectively.

\section{Results}

A total of 48,792 students from Menoufia University (Egypt) participated in the present study to estimate the HCV seroprevalence among them. The participants included 27,421 (56.2\%) females and 21,371 (43.8\%) males, and the mean age was $18 \pm 0.056$ years. According to the place of origin, 1,448 (3\%) students were from Upper Egypt while the majority (47,344 students representing 97\%) were from Lower Egypt. More definitely, we found that the place of residence was rural areas in 20,057 (41.1\%) while students from urban areas were 28,735 (58.9\%) (Table 1$)$. 
Concerning seroprevalence of anti-HCV among the studied subjects, we found that 498 persons (1\%) were positive for anti-HCV. Frequency of anti-HCV was statistically higher among females compared to males (304 females [1.1\%] vs 194 males [0.9\%]). HCV RNA, as detected by quantitative PCR, was positive in 355 students. They represent $0.7 \%$ of the total subjects and $71.3 \%$ of seropositive candidates. No significant difference was found between both the sexes (Table 2).

In our study, we tried to determine the primary source of infection. We found that dental care, family history of $\mathrm{HCV}$, surgical operation, diabetes mellitus (on insulin treatment), and blood transfusion were the predominant risk factors for $\mathrm{HCV}$ infection. They were reported in 33.9\%, 31.5\%, 8.6\%, $7.6 \%$, and $5.2 \%$ of the subjects with anti-HCV-positives, respectively (Table 3).

Table I Sociodemographic features of the students

\begin{tabular}{|l|l|l|}
\hline Category & Students (N=48,972), n (\%) \\
\hline \multirow{3}{*}{ Gender } & Male & $21,37 I(43.8)$ \\
\cline { 2 - 3 } & Female & $27,42 I(56.2)$ \\
\hline Age (years) & Mean & $18 \pm 0.056$ \\
\hline Place of origin & Upper Egypt & $1,448(3)$ \\
\cline { 2 - 3 } & Lower Egypt & $47,344(97)$ \\
\hline \multirow{3}{*}{ Place of residence } & Rural & $20,057(41.1)$ \\
\cline { 2 - 3 } & Urban & $28,735(58.9)$ \\
\hline \multirow{2}{*}{$\begin{array}{l}\text { Family history of } \\
\text { HCV }\end{array}$} & Positive & $10,868(22.3)$ \\
\cline { 2 - 3 } & Negative & $37,924(77.7)$ \\
\hline
\end{tabular}

Abbreviation: $\mathrm{HCV}$, hepatitis $\mathrm{C}$ virus.
Although we found no statistical significant difference in the distribution of anti-HCV in relation to the place of origin, anti-HCV positivity was significantly higher among males $(100 \%)$ than females $(0.9 \%)$ in Upper Egypt. On the other hand, anti-HCV positivity was significantly higher in females $(1.1 \%)$ than males $(0.9 \%)$ in Lower Egypt. The current study showed that anti-HCV seropositivity was significantly higher in rural than urban areas. In addition, females (2\%) were significantly higher than males $(1.1 \%)$ in rural areas while no significant difference was detected between both sexes in urban regions (Table 4).

HCV RNA-positive students were significantly higher in Lower than Upper Egypt, and males were significantly higher than females in Upper Egypt. On the other hand, there was no significant difference between both sexes in Lower Egypt. Also, PCR positives were significantly higher in rural than urban areas. Females (1.4\%) were significantly higher than males $(0.8 \%)$ in rural areas while no significant difference between both sexes in urban areas (Table 5).

\section{Discussion}

The current study aimed to determine the seroprevalence of HCV among students in Menoufia University. Included participants were 27,421 females (56.2\%) and 21,371 males (43.8\%) with a mean age of $18 \pm 0.056$ years. In our study, the anti-HCV prevalence was 498/48,792 (1\%). In 2009, Lehman and Wilson concluded that HCV prevalence in Egypt was around $12 \%$ when they used data collected in the same governorate (Menoufia Governorate). ${ }^{23}$ A recent study that included various systemic reviews, meta-analyses, and

Table 2 Seroprevalence of anti-HCV among the students and HCV RNA positivity (among the students than among the anti-HCVpositive students)

\begin{tabular}{|c|c|c|c|}
\hline Studied subjects & Positive, n (\%) & Negative, n (\%) & P-value \\
\hline \multicolumn{4}{|l|}{ Anti-HCV seroprevalence } \\
\hline Students $(n=48,792)$ & $498(1)$ & $48,294(99)$ & \\
\hline \multicolumn{4}{|l|}{ Gender } \\
\hline Males & $194(0.9)$ & $21,177(99.1)$ & 0.029 \\
\hline Females & $304(1.1)$ & $27,117(98.9)$ & \\
\hline \multicolumn{4}{|c|}{ HCV RNA-positive by PCR among the students } \\
\hline Students $(n=48,792)$ & $355(0.7)$ & $48,437(99.3)$ & \\
\hline \multicolumn{4}{|l|}{ Gender } \\
\hline Males & 147(0.7) & $21,224(99.3)$ & 0.362 \\
\hline Females & $208(0.8)$ & $27,213(99.2)$ & \\
\hline \multicolumn{4}{|c|}{ HCV RNA-positive by PCR among anti-HCV-positive students } \\
\hline Anti-HCV-positive students (498) & $355(7 I .3)$ & $143(28.7)$ & \\
\hline \multicolumn{4}{|l|}{ Gender } \\
\hline Males & 147 (75.8) & $47(24.2)$ & 0.077 \\
\hline Females & $93(31.6)$ & $208(68.4)$ & \\
\hline
\end{tabular}

Abbreviation: $\mathrm{HCV}$, hepatitis $\mathrm{C}$ virus. 
Table 3 Possible sources of HCV infection among the students

\begin{tabular}{|c|c|c|c|c|}
\hline \multirow[t]{2}{*}{ Risk factors } & \multicolumn{3}{|l|}{ Anti-HCV } & \multirow[t]{2}{*}{$P$-value } \\
\hline & Negative $(n=48,294), n(\%)$ & Positive (n=498), n (\%) & Total $(n=48,792), n(\%)$ & \\
\hline \multicolumn{5}{|c|}{ Blood transfusion } \\
\hline Yes & $6(0)$ & $26(5.2)$ & $32(0.1)$ & \multirow[t]{2}{*}{0.000} \\
\hline No & $48,288(100)$ & $472(94.5)$ & $48,760(99.9)$ & \\
\hline \multicolumn{5}{|l|}{ Dental care } \\
\hline Yes & $4,999(10.4)$ & $169(33.9)$ & $5,168(10.6)$ & \multirow[t]{2}{*}{0.000} \\
\hline No & $43,295(89.6)$ & $329(66.1)$ & $43,624(89.4)$ & \\
\hline \multicolumn{5}{|c|}{ Surgical operation } \\
\hline Yes & $101(0.2)$ & $43(8.6)$ & $144(0.3)$ & \multirow[t]{2}{*}{0.000} \\
\hline No & $48,193(99.8)$ & $455(9 \mid .4)$ & $48,648(99.7)$ & \\
\hline \multicolumn{5}{|c|}{ Family history of $\mathrm{HCV}$} \\
\hline Yes & $|0,7| \mid(22.2)$ & $157(3 \mid .5)$ & $10,868(22.3)$ & \multirow[t]{2}{*}{0.000} \\
\hline No & $37,583(77.8)$ & $34 I(68.5)$ & 37,924 (77.7) & \\
\hline \multicolumn{5}{|c|}{ Diabetes mellitus (on insulin) } \\
\hline Yes & $61(0.1)$ & $38(7.6)$ & $99(0.2)$ & \multirow[t]{2}{*}{0.000} \\
\hline No & $48,233(99.9)$ & $460(92.4)$ & $48,693(99.8)$ & \\
\hline
\end{tabular}

Table 4 Anti-HCV in relation to the place of origin and place of residence

\begin{tabular}{|c|c|c|c|c|c|c|c|c|c|c|}
\hline \multirow[t]{2}{*}{$\begin{array}{l}\text { Anti- } \\
\text { HCV }\end{array}$} & \multicolumn{2}{|c|}{$\begin{array}{l}\text { Lower Egypt, } \\
n=47,344 \text { (97\%) }\end{array}$} & \multicolumn{2}{|c|}{$\begin{array}{l}\text { Upper Egypt, } \\
n=1,448(3 \%)\end{array}$} & \multirow[t]{2}{*}{$P$-value } & \multicolumn{2}{|c|}{$\begin{array}{l}\text { Rural, } n=20,057 \\
\text { (4I.1\%) }\end{array}$} & \multicolumn{2}{|c|}{$\begin{array}{l}\text { Urban, } n=28,735 \\
(58.9 \%)\end{array}$} & \multirow[t]{2}{*}{$P$-value } \\
\hline & $\begin{array}{l}\text { Male, } \\
n=21,365 \\
(45.1 \%)\end{array}$ & $\begin{array}{l}\text { Female, } \\
n=25,979 \\
(54.9 \%)\end{array}$ & $\begin{array}{l}\text { Male, } \\
n=6 \\
(0.4 \%)\end{array}$ & $\begin{array}{l}\text { Female, } \\
n=I, 442 \\
(99.6 \%)\end{array}$ & & $\begin{array}{l}\text { Male, } \\
n=10,937 \\
(54.5 \%)\end{array}$ & $\begin{array}{l}\text { Female, } \\
n=9,120 \\
(45.5 \%)\end{array}$ & $\begin{array}{l}\text { Male, } \\
n=10,434 \\
(36.3 \%)\end{array}$ & $\begin{array}{l}\text { Female, } \\
n=|8,30| \\
(63.7 \%)\end{array}$ & \\
\hline Positive & $\begin{array}{l}188 \\
(0.9 \%)\end{array}$ & $\begin{array}{l}297 \\
(1.1 \%)\end{array}$ & $\begin{array}{l}6 \\
(100 \%)\end{array}$ & \begin{tabular}{|l|}
7 \\
$(0.5 \%)$
\end{tabular} & \multirow[t]{3}{*}{0.637} & $\begin{array}{l}124 \\
(1.1 \%)\end{array}$ & $\begin{array}{l}186 \\
(2 \%)\end{array}$ & $\begin{array}{l}70 \\
(0.7 \%)\end{array}$ & $\begin{array}{l}118 \\
(0.6 \%)\end{array}$ & \multirow[t]{3}{*}{0.000} \\
\hline Negative & $\begin{array}{l}21,177 \\
(99.1 \%)\end{array}$ & $\begin{array}{l}25,682 \\
(98.9 \%)\end{array}$ & \begin{tabular}{|l|}
0 \\
$(0 \%)$
\end{tabular} & \begin{tabular}{|l|}
1,435 \\
$(99.5 \%)$
\end{tabular} & & $\begin{array}{l}10,813 \\
(98.9 \%)\end{array}$ & $\begin{array}{l}8,934 \\
(98 \%)\end{array}$ & $\begin{array}{l}10,364 \\
(99.3 \%)\end{array}$ & $\begin{array}{l}18,183 \\
(99.4 \%)\end{array}$ & \\
\hline$P$-value & \multicolumn{2}{|l|}{0.005} & \multicolumn{2}{|l|}{0.000} & & \multicolumn{2}{|l|}{0.000} & \multicolumn{2}{|l|}{0.792} & \\
\hline
\end{tabular}

Table 5 HCV RNA-positive in relation to the place of origin and place of residence

\begin{tabular}{|c|c|c|c|c|c|c|c|c|c|c|}
\hline \multirow[t]{2}{*}{$\begin{array}{l}\text { HCV } \\
\text { RNA }\end{array}$} & \multicolumn{2}{|c|}{$\begin{array}{l}\text { Lower Egypt, } n=47,344 \\
(97 \%)\end{array}$} & \multicolumn{2}{|c|}{$\begin{array}{l}\text { Upper Egypt, } \\
\mathrm{n}=\mathrm{I}, \mathbf{4 4 8}(3 \%)\end{array}$} & \multirow[t]{2}{*}{$P$-value } & \multicolumn{2}{|c|}{$\begin{array}{l}\text { Rural, } n=20,057 \\
(41.1 \%)\end{array}$} & \multicolumn{2}{|c|}{$\begin{array}{l}\text { Urban, } n=28,735 \\
(58.9 \%)\end{array}$} & \multirow[t]{2}{*}{$P$-value } \\
\hline & $\begin{array}{l}\text { Male, } \\
n=21,365\end{array}$ & $\begin{array}{l}\text { Female, } \\
n=25,979\end{array}$ & $\begin{array}{l}\text { Male, } \\
n=6\end{array}$ & $\begin{array}{l}\text { Female, } \\
n=I, 442\end{array}$ & & $\begin{array}{l}\text { Male, } \\
n=10,937 \\
(54.5 \%)\end{array}$ & $\begin{array}{l}\text { Female, } \\
n=9,120 \\
(45.5 \%)\end{array}$ & $\begin{array}{l}\text { Male, } \\
n=10,434 \\
(36.3 \%)\end{array}$ & \begin{tabular}{|l} 
Female, \\
$n=|8,30|$ \\
$(63.7 \%)$
\end{tabular} & \\
\hline Positive & 145 (0.7\%) & $206(0.8 \%)$ & \begin{tabular}{|l} 
\\
$(33.3 \%)$ \\
\end{tabular} & $2(0.1 \%)$ & \multirow[t]{3}{*}{0.040} & $91(0.8 \%)$ & \begin{tabular}{|l|}
131 \\
$(1.4 \%)$ \\
\end{tabular} & $56(0.5 \%)$ & 77 (0.4\%) & \multirow[t]{3}{*}{0.000} \\
\hline Negative & $\begin{array}{l}21,220 \\
(99.3 \%)\end{array}$ & $\begin{array}{l}25,773 \\
(99.2 \%)\end{array}$ & \begin{tabular}{|l|}
4 \\
$(66.7 \%)$
\end{tabular} & $\begin{array}{l}1,440 \\
(99.9 \%)\end{array}$ & & $\begin{array}{l}10,846 \\
(99.2 \%)\end{array}$ & \begin{tabular}{|l|}
8,989 \\
$(98.6 \%)$
\end{tabular} & $\begin{array}{l}0,378 \\
(99.5 \%) \\
\end{array}$ & \begin{tabular}{|l|}
18,224 \\
$(99.6 \%)$
\end{tabular} & \\
\hline$P$-value & \multicolumn{2}{|l|}{0.149} & \multicolumn{2}{|l|}{0.000} & & \multicolumn{2}{|l|}{0.000} & \multicolumn{2}{|l|}{0.164} & \\
\hline
\end{tabular}

meta-regressions to characterize the HCV epidemiology in Egypt among the general population has documented that the pooled mean $\mathrm{HCV}$ prevalence is $11.9 \% .{ }^{24}$ Concerning our studied age group (15-19 years), our rates are definitely lower than that detected by EDHS $2008(4.1 \%)^{7}$ and Esmat et al report that there is $4.6 \%$ seroprevalence of anti-HCV among a comparably similar age group to our participants. ${ }^{25}$ Our reported $\mathrm{HCV}$ prevalence is even lower than that reported for the least affected age group (1-9 years age). A previous study found that asymptomatic $\mathrm{HCV}$ infection in this pediatric age group is $2.02 \% .{ }^{26}$ This confirms again the true decline of $\mathrm{HCV}$ prevalence in the last few years. The recent meta-regression published by Kouyoumjian et al declared $6 \%$ lower odds for prevalence of HCV for each 1-year increment in publication year. ${ }^{24}$ According to Kandeel et al, the main explanation for the reduced prevalence is the exclusion of patients who exceeded 60 years of age from the recent survey while they represent a main pool of HCV patients who were previously infected with HCV in the past years of anti-schistosomiasis campaigns. ${ }^{27}$ The researchers added that HCV antibody 
prevalence at 19 years of age (as students of our study) is a true indicator for the cumulative incidence over the past 20 years. The calculated relative risk reduction between the two demographic surveys is $75 \%$, which provides a true marker of reduced HCV prevalence. ${ }^{27} \mathrm{We}$ assume that the application of preventive precautions for HCV transmission among the general community increased the awareness of $\mathrm{HCV}$, its transmission routes increased the educational level, and the massive treatment programs which were applied in Egypt in the past years have their impact that recently start to glare.

The anti-HCV-positive females (1.1\%) were significantly predominant than males $(0.9 \%)$. This could be somewhat contributed to the higher percentages of females among participated students in our study. Esmat et al also reported higher HCV prevalence among females (5.2\%) than males (3.8\%) but without statistical difference. ${ }^{25}$ Population-based EDHS 2008 documented a higher prevalence in males (5.6\%) than in females $(2.7 \%){ }^{7}$ Also, Nafeh et al declared that HCV prevalence was higher in males than females $(11.3 \%$ vs $6.5 \%) .^{28}$

Active $\mathrm{HCV}$ infection, as evidenced by HCV-RNA positivity, was reported in $0.7 \%$ of studied participants. This is also lower than that reported by Esmat et $\mathrm{al}^{25}$ who found active infection in 1.4\% and EDHS 2008 that reported prevalence of active infection to be $3.1 \%$ in the same age group. ${ }^{7}$

However, our HCV-RNA prevalence among the 498 anti$\mathrm{HCV}$ positive subjects $(71.3 \%)$ is higher than that detected by Nafeh et $\mathrm{al}^{28}$ as well as Esmat et $\mathrm{al}^{25}$ who documented HCV RNA in $62.8 \%$ and $31.4 \%$ of the anti-HCV-positive subjects, respectively. This difference between anti-HCV and HCV RNA positivity is mainly explained by the spontaneous viral clearance through innate immunity response in acute HCV infections..$^{29,30}$ In addition, a study proposed a possible antibody cross reactivity in patients with old bilharzial infection. ${ }^{31}$

Regarding our present study, we found that dental care, family history of HCV, blood transfusion, surgical operations, and diabetes mellitus (all on insulin treatment) were the predominant risk factors for $\mathrm{HCV}$ infection. Iatrogenic transmission is blamed as the main driver of the HCV epidemic in Egypt. ${ }^{32}$ Mohamed et al previously reported that wound sutures, surgery, injections, and intravenous infusions increased the HCV infection probability but without statistical significance..$^{33}$ Also, in a study done by Edris et al, the risk factors for HCV infection were surgery, stitches, dental procedures, contact with infected persons contact, and parenteral schistosomiasis treatment. ${ }^{34}$ Strickland also reported a higher risk of $\mathrm{HCV}$ infection in children of HCV-infected parents. ${ }^{5}$
As expected, the current study showed that HCV infection was more prevalent in rural than urban areas. This is in accordance with EDHS report 2008 that mentioned that infection was more in rural than urban areas (12\% vs $7 \%)$. The same dominance of HCV prevalence in rural areas was documented in all age groups, even in vertical transmission cases. ${ }^{35}$ Rural areas have less strict precautions as regards the different modes of HCV infection and a comparably less awareness about modes of transmission of HCV than urban areas. Guerra et al studied HCV-related morbidities in rural Egyptian communities. Results were striking. Anti-HCV averaged $18.5 \%$ prevalence and reached $45 \%$ in males over 40 years and $30 \%$ in females older than 50 years. ${ }^{36}$ In our study, active infection, as evidenced by HCV RNA positivity, was more frequent among Lower Egyptian Governorates than the Upper ones. Lower Egyptian Governorates, including Menoufia, are predominantly agricultural regions, and farming-related water activities is one of the main occupations in these rural areas. This probably correlates with higher schistosomal affection, more frequent antischistosomal parenteral therapies, lower socioeconomic status, higher incidence of unsafe medical practice, and so higher possibilities for chronic HCV infection. ${ }^{37}$ This raises the importance of managing sources and modes of infection in parallel to the mass treatment programs for $\mathrm{HCV}$ to achieve the goal of $\mathrm{HCV}$ eradication.

\section{Limitations}

Although the study included a large number of students who well represent a certain age group (15-19 years), still we had some limitations. The Upper Egypt region was not enough represented and will need special focus in different studies. In addition, we did not perform HCV RNA for all students, and so we did not have the chance to detect the incidence of acute HCV infections.

\section{Conclusion}

We actually found a declining prevalence of $\mathrm{HCV}$ infection in the same age group which poses better hopes for a possible successful eradication of $\mathrm{HCV}$ as planned.

\section{Acknowledgments}

The authors specially thank professor Gamal Esmat and doctor Tamer Elbaz for their guidance and encouragement in this work.

\section{Disclosure}

The authors report no conflicts of interest in this work. 


\section{References}

1. Averhoff FM, Glass N, Holtzman D. Global burden of hepatitis C: considerations for healthcare providers in the United States. Clin Infect Dis. 2012;55(1):S10-S15.

2. Sievert W, Altraif I, Razavi HA, et al. A systematic review of hepatitis $\mathrm{C}$ virus epidemiology in Asia, Australia and Egypt. Liver Int. 2011;31(2):61-80.

3. Lavanchy D. Evolving epidemiology of hepatitis C virus. Clin Microbiol Infect. 2011;17(2):107-115.

4. Frank C, Mohamed MK, Strickland GT, et al. The role of parenteral antischistosomal therapy in the spread of hepatitis $\mathrm{C}$ virus in Egypt. Lancet. 2000;355(9207):887-891.

5. Strickland GT. Liver disease in Egypt: hepatitis C superseded schistosomiasis as a result of iatrogenic and biological factors. Hepatology. 2006;43(5):915-922.

6. Elbaz T, Esmat G. Hepatic and intestinal schistosomiasis: review. JAdv Res. 2013;4(5):445-452.

7. El-Zanaty F. Way A: Egypt Demographic and Health Survey 2008. Egyptian: Ministry of Health. Cairo: El-Zanaty and Associates, and Macro International; 2009.

8. Mohamoud YA, Mumtaz GR, Riome S, Miller D, Abu-Raddad LJ. The epidemiology of hepatitis $\mathrm{C}$ virus in Egypt: a systematic review and data synthesis. BMC Infect Dis. 2013;13(1):288.

9. Ministry of Health and Population [Egypt], El-Zanaty and Associates [Egypt], and ICF International. Egypt Health Issues Survey 2015. Cairo, Egypt and Rockville, Maryland, USA: Ministry of Health and Population and ICF International; 2015.

10. Breban R, Doss W, Esmat G, et al. Towards realistic estimates of HCV incidence in Egypt. J Viral Hepat. 2013;20(4):294-296.

11. Lozano R, Naghavi M, Foreman K, et al. Global and regional mortality from 235 causes of death for 20 age groups in 1990 and 2010: a systematic analysis for the Global Burden of Disease Study 2010. Lancet. 2012;380(9859):2095-2128.

12. Miller FD, Abu-Raddad LJ. Evidence of intense ongoing endemic transmission of hepatitis C virus in Egypt. Proc Natl Acad Sci U S A. 2010;107(33):14757-14762.

13. Mohamoud YA, Mumtaz GR, Riome S, Miller D, Abu-Raddad LJ. The epidemiology of hepatitis C virus in Egypt: a systematic review and data synthesis. BMC Infect Dis. 2013;13:288.

14. Elwan N, Elfert A, Abd-Elsalam S, et al. Study of Hepatic Steatosis Index in Patients with Chronic HCV Infection. Int J Curr Microbiol Appl Sci. 2016;5(5):266-279.

15. Gad RR, Males S, El Makhzangy H, et al. Predictors of a sustained virological response in patients with genotype 4 chronic hepatitis $\mathrm{C}$. Liver Int. 2008;28(8):1112-1119.

16. Ahmed OA, Kaisar HH, Hawash N, et al. Efficacy of sofosbuvir plus ribavirin with or without peginterferon- alfa in treatment of a cohort of egyptian patients with hepatitis C virus infection. Infect Disord Drug Targets. 2017;17(2):95-100.

17. Abd-Elsalam S, Sharaf-Eldin M, Soliman S, Elfert A, Badawi R, Ahmad YK. Efficacy and safety of sofosbuvir plus ribavirin for treatment of cirrhotic patients with genotype 4 hepatitis $\mathrm{C}$ virus in real-life clinical practice. Arch Virol. 2018;163(1):51-56.

18. Zakaria S, Fouad R, Shaker O, et al. Changing patterns of acute viral hepatitis at a major urban referral center in Egypt. Clin Infect Dis. 2007;44(4):e30-e36.

19. Ahmed OA, Elsebaey MA, Fouad MHA, et al. Outcomes and predictors of treatment response with sofosbuvir plus daclatasvir with or without ribavirin in Egyptian patients with genotype 4 hepatitis $\mathrm{C}$ virus infection. Infect Drug Resist. 2018;11:441-445.
20. Ahmed OA, Kaisar HH, Badawi R, et al. Efficacy and safety of sofosbuvir-ledipasvir for treatment of a cohort of Egyptian patients with chronic hepatitis C genotype 4 infection. Infect Drug Resist. 2018;11: 295-298.

21. Ahmed OA, Safwat E, Khalifa MO, et al. Sofosbuvir plus daclatasvir in treatment of chronic hepatitis $\mathrm{C}$ genotype 4 infection in a cohort of egyptian patients: an experiment the size of egyptian village. Int $J$ Hepatol. 2018;2018:9616234

22. Klevens RM, Moorman AC. Hepatitis C virus: an overview for dental health care providers. J Am Dent Assoc. 2013;144(12): 1340-1347.

23. Lehman EM, Wilson ML. Epidemic hepatitis C virus infection in Egypt: estimates of past incidence and future morbidity and mortality. J Viral Hepat. 2009;16(9):650-658.

24. Kouyoumjian SP, Chemaitelly H, Abu-Raddad LJ. Characterizing hepatitis C virus epidemiology in Egypt: systematic reviews, meta-analyses, and meta-regressions. Sci Rep. 2018;8(1):1661.

25. Esmat G, Raziky ME, Nabeel MM, Maher R, Zakaria Z. Seroprevalence of HCV among Cairo University students in Egypt. J Med Virol. 2016;88(8):1384-1387.

26. El-Raziky MS, El-Hawary M, Esmat G, et al. Prevalence and risk factors of asymptomatic hepatitis $\mathrm{C}$ virus infection in Egyptian children. World J Gastroenterol. 2007;13(12):1828-1832.

27. Kandeel A, Genedy M, El-Refai S, Funk AL, Fontanet A, Talaat M. The prevalence of hepatitis $C$ virus infection in Egypt 2015: implications for future policy on prevention and treatment. Liver Int. 2017;37(1): 45-53.

28. Nafeh MA, Medhat A, Shehata M, et al. Hepatitis C in a community in Upper Egypt: I. Cross-sectional survey. Am J Trop Med Hyg. 2000;63(5-6):236-241.

29. Micallef JM, Kaldor JM, Dore GJ. Spontaneous viral clearance following acute hepatitis $\mathrm{C}$ infection: a systematic review of longitudinal studies. J Viral Hepat. 2006;13(1):34-41.

30. Abd Elrazek AE, Bilasy SE, Elbanna AE, Elsherif AE. Prior to the oral therapy, what do we know about HCV-4 in Egypt: a randomized survey of prevalence and risks using data mining computed analysis. Medicine. 2014;93(28):e204.

31. Agha S, El-Mashad N, El-Malky M, et al. Prevalence of low positive anti-HCV antibodies in blood donors: Schistosoma mansoni co-infection and possible role of autoantibodies. Microbiol Immunol. 2006;50(6):447-452.

32. Miller FD, Elzalabany MS, Hassani S, Cuadros DF. Epidemiology of hepatitis $\mathrm{C}$ virus exposure in Egypt: Opportunities for prevention and evaluation. World J Hepatol. 2015;7(28):2849-2858.

33. Mohamed MK, Abdel-Hamid M, Mikhail NN, et al. Intrafamilial transmission of hepatitis C in Egypt. Hepatology. 2005;42(3): 683-687.

34. Edris A, Nour MO, Zedan OO, Mansour AE, Ghandour AA, Omran T. Seroprevalence and risk factors for hepatitis B and $\mathrm{C}$ virus infection in Damietta Governorate, Egypt. East Mediterr Health J. 2014;20(10): 605-613.

35. Benova L, Awad SF, Miller FD, Abu-Raddad LJ. Estimation of hepatitis $\mathrm{C}$ virus infections resulting from vertical transmission in Egypt. Hepatology. 2015;61(3):834-842.

36. Mohamed MK, Bakr I, El-Hoseiny M, et al. HCV-related morbidity in a rural community of Egypt. J Med Virol. 2006;78(9): 1185-1189.

37. Guerra J, Garenne M, Mohamed MK, Fontanet A. HCV burden of infection in Egypt: results from a nationwide survey. JViral Hepat. 2012;19(8): 560-567. 
Infection and Drug Resistance is an international, peer-reviewed openaccess journal that focuses on the optimal treatment of infection (bacterial, fungal and viral) and the development and institution of preventive strategies to minimize the development and spread of resistance. The journal is specifically concerned with the epidemiology of antibiotic resistance and the mechanisms of resistance development and diffusion in both hospitals and the community. The manuscript management system is completely online and includes a very quick and fair peerreview system, which is all easy to use. Visit http://www.dovepress.com/ testimonials.php to read real quotes from published authors.

Submit your manuscript here: https://www.dovepress.com/infection-and-drug-resistance-journal 